С.Г. Кійко

ПрАТ Електрометалургійний завод “Дніпроспецсталь” ім. А.М. Кузьміна, Запоріжжя

\title{
ПЛАНУВАННЯ ЕНЕРГОСПОЖИВАННЯ ПРИ РЕАЛІЗАЦІЇ ПОРТФЕЛЯ ПРОЕКТІВ ЕНЕРГОЗБЕРЕЖЕННЯ НА МЕТАЛУРГІЙНОМУ ПІДПРИЄМСТВІ НА БАЗІ ПРЕДИКТИВНОЇ АДАПТАЦІЇ
}

\begin{abstract}
Запропоновано методологію управління портфелями проектів енергозбереження на металургійних підприємствах, яка формує парадигму предиктивної адаптаиії, що базується на взаємопов'язаних адаптивних системах планування, моніторингу і управління змінами та дозволяє на основі прогнозування енергоспоживання для складних технологічних процесів і виробництв, а також моделювання і очінки якості паливно-енергетичного балансу, в умовах обмеженості ресурсів і ризиків здійснювати формування $і$ відбір для реалізації проектів енергозбереження при узгодженні пріоритетів бізнес-стратегії $і$ стратегї енергоефективності металургійного підприсмства. Побудовано агентну імітаційну модель для вирімення завдань $з$ управління розподілом енергоресурсів, яка заснована на взаємодії агентів постачальників, споживання, виробництва і перетворення, виконуючих пошук відповідності на внутрішньозаводському ринку наявних енергоресурсів або зовнішньому енергоринку, щьо дозволяє комплексно з урахуванням динаміки виробничих процесів проводити аналіз та вибір варіантів реалізачії проектів портфеля енергозбереження. За допомогою цъього програмного комплексу проводиться порівняння допустимих значень і коригування величини прогнозованого споживання активної потужності металургійним підприсмством за кожен фіксований момент часу. Система обчислює діапазони регулювання дугових електропечей, допустимі для забезпечення безперервності розливання сталі при плавичі певного сортаменту стали за відповідним технологічним маршрутом. Також в модель закладені алгоритми управління транспортним устаткуванням, які мінімізують розриви в роботі машин безперервного лиття. Проведено аналіз результатів імітаційного моделювання прочесів енергоспоживання на металургічному підприємстві. В результаті моделювання вдалося підвищити продуктивність групи дугових сталеплавильних печей $і$ агрегатів піч-ківш, знизити максимальне споживання активної потужності металургійним підприсмством за фіксований час доби. Проведено експериментальні дослідження методів планування енергоспоживання на основі реальних даних з вироблення металопродукції $i$ електроспоживання виробничими підрозділами ПрАТ “Дніпроспецсталь”.
\end{abstract}

Ключові слова: портфель проектів, управління енергозбереженням, металургійне підприємство, планування енергоспожсивани, агентна модель.

\section{Вступ}

Постановка проблеми. Виробництво сталі складний процес, що включає в себе множину операцій, які необхідно скоординувати одну з одною. Тому дуже важко передбачити, як вплине на виробничі процеси реалізація проектів та заходів 3 програми енергозбереження, зміна асортименту продукції або операційних правил. Була необхідна детальна модель, щоб передбачити наслідки змін, необхідних для підвищення енергоефективності виробництва.

Наявність цілісної моделі енергоспоживання для металургійних підприємств дозволяє оцінити ефективність відібраних проектів реалізації енергозберігаючих заходів, об'єктивно оцінити частку кожного енергоресурсу в загальному потоці, визначити енергоємність окремого виробництва, цеху, всього підприємства, скорегувати стратегічний напрямок в управлінні енергоресурсами.

На підприємстві є прилади обліку, які вимірю- ють фактичне споживання енергоресурсів. У загальному випадку існує неузгодженість або небаланс між фактичним енергоспоживанням підприємства і сумарним фактичним енергоспоживанням окремих підрозділів. Потрібно вирішення завдання мінімізації загальної помилки прогнозу споживання енергії кожного виду підприємством, яке засноване на неузгодженості значень фактичного загального споживання енергії підприємством, що визначається за показниками приладів обліку, і розрахункових сумарних витрат енергоресурсів.

Але проблема прогнозування і планування енергоспоживання в металургійному виробництві являє собою складне багатопараметричне завдання, що має вірогідну складову, а причинний зв'язок енергоспоживання $з$ кожним $з$ цих параметрів досить складний i не має однозначного формального опису. Моделювання дозволило відобразити всі елементи виробничої системи у віртуальному середовищі. 
Аналіз останніх досліджень і публікацій. Багато дослідників розглядають принципи і особливості вирішення таких завдань як енергетичне обстеження, енергетичний моніторинг і планування. При цьому підкреслюється, що на стратегічному рівні металургійними підприємствами реалізуються цільові програми 3 енергозбереження з урахуванням особливостей конкретного підприємства, а до тактичних кроків відносять організацію обліку витрачання енергоресурсів на різних рівнях.

В роботі [1] сформулювали основні проблеми управління електроспоживання балансується і енергозбереженням в металургійному виробництві i привели можливі шляхи їх вирішення. В роботі розглянуті завдання нормування, планування енерговитрат за рівнями управління. Авторами запропонований метод прогнозування витрат енергоресурсів, заснований на побудові регресійних моделей 3 включенням фактору часу.

Рішення завдання прогнозування електроспоживання на основі багатофакторного регресійного i кореляційного аналізів здійснюється в роботах [24]. В роботі [5] оцінка і прогнозування електроспоживання в енергосистемах здійснюється на основі нечіткого регресійного аналізу. В роботі [6] використовуються гібридні мережі Петрі для моделювання та аналізу металургійних процесів. Динамічний потік матеріалів і зміни в реальному часі кожного технологічного стану в металургійному процесі наочно моделюються за допомогою цієї моделі.

У роботі [7] для прогнозування енергоспоживання підприємств металургії запропоновано використовувати нейронні мережи та глибоке навчання, а саме модель LSTM.

У роботі [8] запропонований метод прогнозування електроспоживання на металургійному підприємстві що враховує такі складові: споживання енергії, де обладнання не змінюється протягом усього прогнозу; споживання енергії, де планується перехід на сучасне технологічне обладнання; споживання енергії з новим обладнанням та технологією.

Авторами в роботі [9] розглянуті теоретичні та практичні аспекти оперативного планування i управління електроспоживання балансується на промисловому підприємстві. Представлені можливості математичного моделювання та оптимізації технологічних режимів. На прикладі агломераційного виробництва великого металургійного комбінату виконані розрахунки оптимально-компромісного режиму. Показано, що в результаті рішення задачі координації змінна продуктивність аглофабрики збільшиться, а електроспоживання скоротиться.

Сутність процесу підвищення енергоефективності виробництва полягає в зниженні питомих витрат енергоносіїв на виробництво продукції, в раціоналізації режимів енерговикористання, зміні струк- тури енергоспоживання, підвищення екологічної ефективності виробництва [10].

Підвищення ефективності промислового виробництва, головним чином, через впровадження ресурсо- і енергозберігаючих технологій, обладнання та процесів викликала необхідність коригування пріоритетних напрямів розвитку енергоємних галузей промисловості, в тому числі підприємств металургійного комплексу [11].

У роботі [12] представлені концептуальні положення для управління портфелями проектів в організації та формалізація методологічних засад створення ціннісно-орієнтованого портфелю проектів розвитку металургійних підприємств.

Мета статті. Дослідження розв'язує актуальну науково-прикладну проблему створення та впровадження методологічних основ управління портфелями проектів енергозбереження на металургійних підприємствах, з урахуванням стратегічних цілей, обмеженості ресурсів і ризиків. Наукова гіпотеза дослідження грунтується на припущенні, що побудова ефективної системи менеджменту проектів та програм енергозбереження на металургійних підприємствах, яка буде базуватися на предиктивній аналітиці енергоспоживання та якості паливно-енергетичного балансу й включати взаємозалежні адаптивні системи планування, моніторингу та управління змінами дозволить більш ефективніше формувати та реалізовувати портфель проектів енергозбереження на металургійних підприємствах та сприяти підвищенню енергоефективності та конкурентоспроможності підприємств металургійної галузі України. Аналіз та прогнозування енергоспоживання на металургійному підприємстві буде здійснено шляхом побудови агентної імітаційної моделі, яка охоплює всі процесі у виробництві металопродукції.

\section{Виклад основного матеріалу}

\section{Методологія предиктивної адаптації при управлінні портфелем енергозберігаючих проектів металургійного підприємства}

Концепція управління портфелем енергозберігаючих проектів базується на кількох взаємозалежних адаптивних системах: планування та формування, моніторингу та управління змінами [13].

Формою вирішення основного протиріччя процесу реалізації портфеля проектів енергозбереження на металургійному підприємстві і інструментом організації енергоекономічних зв'язків між процесами енергоспоживання та енергозбереження $\epsilon$ механізм предиктивної (прогнозної) адаптації при комплексному управлінні енергоспоживанням металургійного підприємства. По-перше, це предиктивна аналітика енергоспоживання та якості паливно-енергетичного балансу. По-друге, важливе значення при динамічно- 
му аналізі та формуванні паливно-енергетичного балансу на металургійному підприємстві має саме блок адаптивного зворотного зв'язку, що здійснює контроль енергоспоживання і контроль досягнення цілей енергетичної програми та цілей реалізації проектів енергозбереження, що було відібрано до портфелю [14-15]. За допомогою відповідних управлінських рішень це впливає на формування динамічних нормативів для управління підсистемою енергоспоживання, на оптимальну побудову енергетичних характеристик iз заданою точністю за критерієм мінімуму технікоекономічних втрат, на вирішення завдання мінімізації загальної помилки прогнозу споживання енергоресурсів, на аналіз енергоефективності, розподіл ресурсів для програми енергозбереження та корегування пріоритетів енергетичної стратегії. Таким чином, формується гнучкий адаптивний механізм оптимізації енергетичних активів для підтримки високої оцінки якості паливно-енергетичного балансу металургійного підприємства, що забезпечує узгодження ефективної енергетичної стратегії та стратегії розвитку бізнеспроцесів. Це дозволяє готувати управлінські рішення тоді, коли вже з'являються відповідні значення індикаторів та сигнали, за якими можна помітити ранні ознаки настання важливих подій в енергетичної ситуації та для прийняття попереджувального управління енергоспоживанням та реалізацією проектів енергозбереження.

Результати, одержані при прогнозуванні енергоспоживання, служать попередньою базовою інформацією на всіх етапах планування та управління процесом енергоспоживання підприємства. При цьому адаптивний енергетичний менеджмент має форму i методи портфельного управління, які дають системі можливість змінювати параметри підсистеми планування та реалізації проектів енергозбереження і одночасно регуляторів енергоспоживання на металургійному підприємстві в залежності від трансформації внутрішніх параметрів процесів енергоспоживання або зовнішніх факторів (цін і тарифів, попиту і пропозиції енергоресурсів, питомих норм тощо), а також від зміни стратегічних цілей і пріоритетів. Як механізми адаптивного зміни в системі планування розглядаються наступні: коригування розкладів (так в залежності від результатів моделювання перспективного енергоспоживання і досягнення цільових показників енергоефективності збільшується або зменшується тривалість етапів проектів); зміна пріоритетів (тут змінюється план незавершених робіт в залежності від результатів аналізу попередніх етапів реалізації проектів енергозбереження і на основі динамічної оцінки якості паливно-енергетичного балансу металургійного підприємства); перерозподіл ресурсів та ін. Багаторівнева модель планування енергоспоживання металургійного підприємства при реалізації портфеля проектів енергозбереження представлена на рис. 1. У багаторівневій моделі планування енергоспоживання металургійного підприємства можна виділити три організаційних рівня (споживання енергії на загальновиробничому, загальногосподарському і технологічному рівнях) і два рівня тимчасового планування (місячне і добове планування).

Основні розв'язувані завдання при управлінні портфелем проектів енергозбереження:

- оптимізація - розподіл ресурсів з метою максимізації цінності портфеля з урахуванням таких його показників, як рентабельність, ROI, NPV, IRR, ризик та ін.;

- балансування - досягнення бажаної рівноваги ресурсів в проектах через такі параметри як ризик i ROI, короткостроковість і довгостроковість проекту та ін.;

- стратегічне вирівнювання - гарантування того, що фіксований обсяг ресурсів при виконанні проектів підприємства буде витрачатися відповідно до досягнення стратегічних цілей підприємства. Тут здійснюється перехід до більш зрілих моделей управління проектами оскільки, до основних показників проекту: вартість, час і якість, додається ще один показник відповідність стратегії;

- пріоритезація - ранжування проектів портфеля для досягнення найкращого балансу між потребами в ресурсах та їх наявністю. У цьому завданні розподіл ресурсів між проектами буде відбуватися відповідно до встановлених пріоритетів проектів. У найпростішому випадку, ця технологія виділяє ресурси проектам 3 найбільшим пріоритетом, а ті проекти, яким ресурсу не вистачає - призупиняє;

- реалізація - гарантування того, що в умовах наявних потреб і достатності обмежених ресурсів будуть досягнуті результати проекту та планові показники за термінами, вартості та якості.

\section{Імітаційна модель енергоспоживання на металургійному підприємстві}

Щоб повністю врахувати всі взаємозалежності, обмеження, динаміку і невизначеності, було створено імітаційну модель енергоспоживання на металургійному підприємстві, яка охоплює всі процесі у виробництві металопродукції [16]. Імітаційна модель автоматизованого металургійного виробництва розроблена у середовищі Anylogic та складається 3 компонент, кожен з яких відображає окремий елемент динаміки поведінки металургійного комплексу. У розробленій імітаційній моделі за допомогою класу активних об'єктів (агентів) реалізовані: дугова сталеплавильна піч (ДСП); сталевоз сталеплавильного цеху; сталевоз дільниці позапічної обробки стали; агрегат піч-ківш (АПК); кран дільниці позапічної обробки стали; кран дільниці розливу стали; машина безперервного лиття заготовок (МБЛЗ); прокатний модуль. 


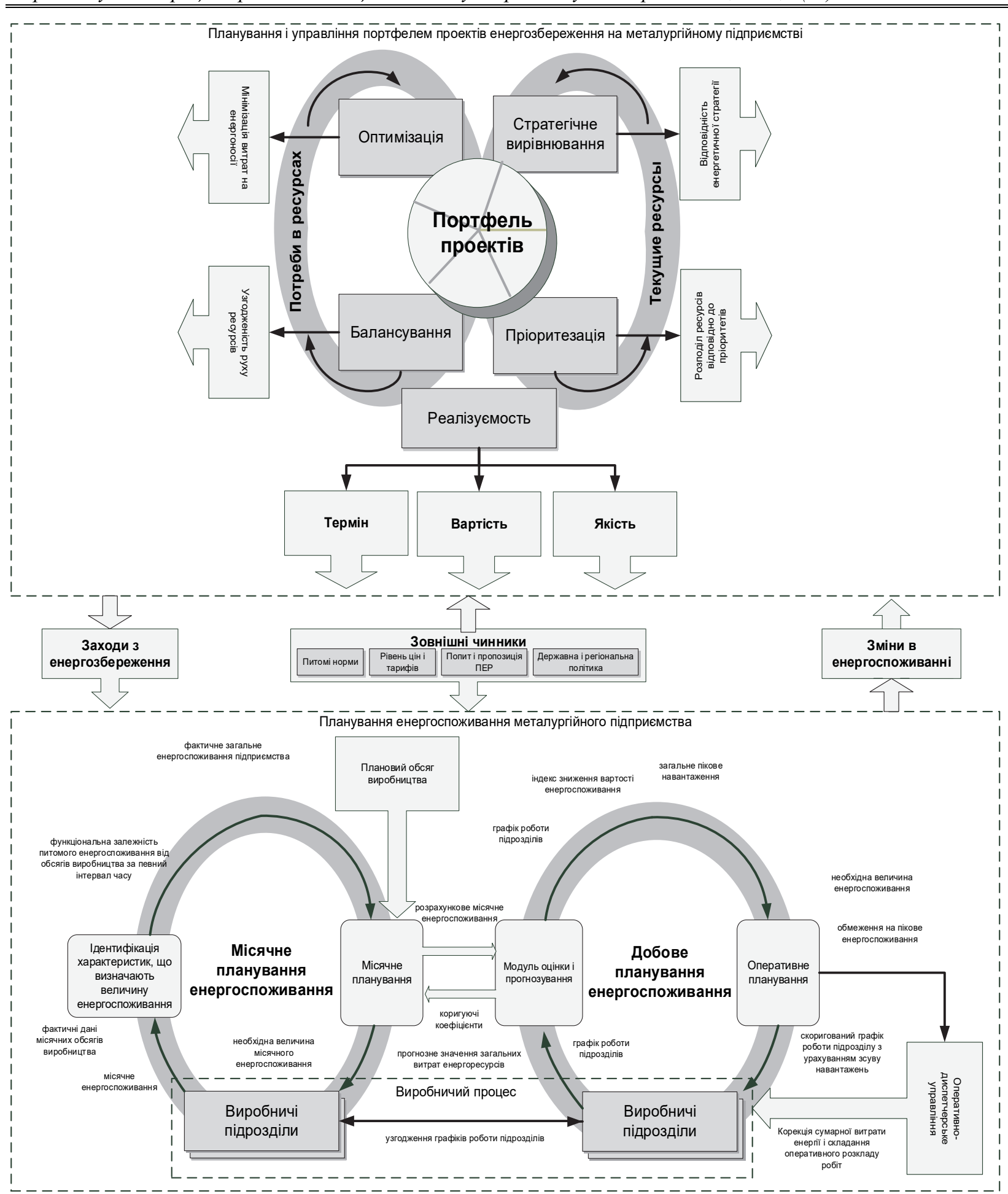

Рис. 1. Багаторівнева модель планування енергоспоживання при реалізації портфеля проектів енергозбереження

Джерело: розроблено автором.

Одним із завдань моделювання енергоспоживання на металургійному підприємстві є підвищення продуктивності групи дугових сталеплавильних печей і агрегатів піч-ківш за рахунок виключення їх простоїв, обумовлених порушенням безперервності розливання сталі внаслідок позаштатних ситуацій, i зниження максимального споживання активної потужності металургійним підприємством за фіксова- ний час доби за допомогою використання існуючих резервів 3 регулювання потужності виробничих установок.

Для побудови моделі було використано інформацію про існуючі технологічні маршрути при плавці сталі заданого сортаменту на ПрАТ “Дніпроспецсталь”, для кожного з яких відомі: виробничі установки, що використовуються в певній послідовнос- 
ті, часові діапазони виконання виробничих операцій на кожній виробничій установці, величина активної потужності, споживаної кожною установкою.

Автоматизована система технічного обліку електроенергії передає в систему моделювання величину прогнозованого споживання активної потужності металургійним підприємством за кожен фіксований час доби, а також допустиме значення активної потужності. Споживання активної потужності металургійним підприємством за кожен фіксований час доби складається з активної потужності, споживаної ДСП, АПК, МБЛЗ і іншими споживачами електроенергії металургійного підприємства за відповідний фіксований час доби.

Дані про величину прогнозованого споживання активної потужності металургійного підприємства за кожен фіксований час доби, заносяться в систему щодня на наступну добу вперед на підставі прогнозу, що виконується управлінням головного енергетика. В якості допустимого значення активної потужності виступає заявлене іiі значення для металургійного підприємства. Коригування заданого технологічного маршруту полягає в зміні послідовності використання виробничих установок, тривалості виконання виробничих операцій на виробничих установках, а також додання або видалення деяких виробничих установок по результатах прогонів імітаційної моделі.

Автоматизована система управління технологічним процесом сталеплавильного виробництва отримує сигнали з датчиків і контролерів і здійснює моніторинг тривалості виконання технологічних операцій на виробничих установках кожного технологічного маршруту і обчислює діапазони регулювання для дугових електропечей, що є допустимі для забезпечення безперервності розливання сталі при плавці певного сортаменту стали за відповідним технологічним маршрутом. За допомогою програмного комплексу проводиться порівняння допустимих значень і коригування величини прогнозованого споживання активної потужності металургійним підприємством за кожен фіксований час доби в залежності від введення витримки часу перед пуском ДСП i/або АПК. Далі за допомогою автоматизованої системи управління режимами роботи ДСП відбувається подача сигналів на спеціального агентаконтролера обладнання для запуску кожної готової до пуску ДСП з витримкою часу, що не перевищує тривалість періоду розплаву ДСП, попереднього по запуску. При цьому це значення не повинно виходити за межі діапазонів регулювання ДСП, допустимих для забезпечення безперервності розливання сталі при плавці певного сортаменту стали за відповідним технологічним маршрутом.

Якщо величина прогнозованого споживання активної потужності металургійним підприємством за вказаний фіксований час доби перевищує допустиме значення активної потужності, то подається сигнал на агента-контролера обладнання на запуск кожного готового до пуску агрегату піч-ківш 3 можливим зміщенням електричного режиму з зазначеної фіксованої години доби в фіксовану годину доби, що $\epsilon$ наступною за зазначеною, без порушення безперервності розливання сталі при плавці певного сортаменту сталі з використанням запуску агрегату піч-ківш по іншому технологічному маршруту 3 введенням витримки часу перед цим запуском.

На рис. 2 представлено випробувальний стенд у процесі моделювання.

Після завантаження в ДСП металошихти і сипучих матеріалів, запалюється електрична дуга i включаються газокисневі пальники, починається процес виплавки сталі. Після досягнення заданої температури і хімічного складу, сталь через еркерній отвір печі зливається в сталерозливних ківш, який встановлений на сталевоза. Перед випуском плавки проводиться попередній розігрів стальковша на установці розігріву, що розміщується над шляхами сталевоза ДСП. Після випуску плавки, сталерозливних ківш самохідним сталевозом подається в роздавальний проліт, в зону дії ливарного крана для транспортування на позапічну обробку (установку ківш-піч).

На рис. 3 представлено імітаційну модель дугової сталеплавильної печі. Основні параметри: максимальна потужність, максимальний об'єм завантаження, час роботи відповідно до режимів. Для накопичування статистики по енергоспоживанню додано відповідний датасет та змінні. Поведінку агента ДСП задано за допомогою діаграми станів, де враховано такі події, як початок періоду розплаву; закінчення періоду розплаву (початок періоду плавлення); закінчення періоду доведення (початок простою печі); очікування сталевозу; завантаження сталевозу. Аналогічно було створено моделі інших елементів - сталевоз сталеплавильного цеху; сталевоз дільниці позапічної обробки стали; АПК; кран дільниці позапічної обробки стали; кран дільниці розливу стали; МБЛЗ та прокатний модуль.

Спостерігаючи за процесом моделювання можна побачити поточне та сумарне значення електроспоживання; об'єм виробництва сталі; сумарний графік навантаження металургійного підприємства, що змінюється у режимі модельного часу; діаграма Ганта (із зазначенням ранніх і пізніх термінів початку і закінчення технологічних операцій); діаграми та відповідні значення коефіцієнтів завантаження основного обладнання та транспортних засобів.

Модель повністю анімовано як у 2D так і у 3D. Також розроблені алгоритми управління транспортним устаткуванням, що спрямовані на мінімізацію розривів в роботі МБЛЗ. 
Завдяки багатоваріантним розрахункам на імітаційній моделі транспортного обслуговування вибираються раціональні маршрути руху транспорту в залежності від постановок задач оптимізації енергоспоживання та логістичного управління.

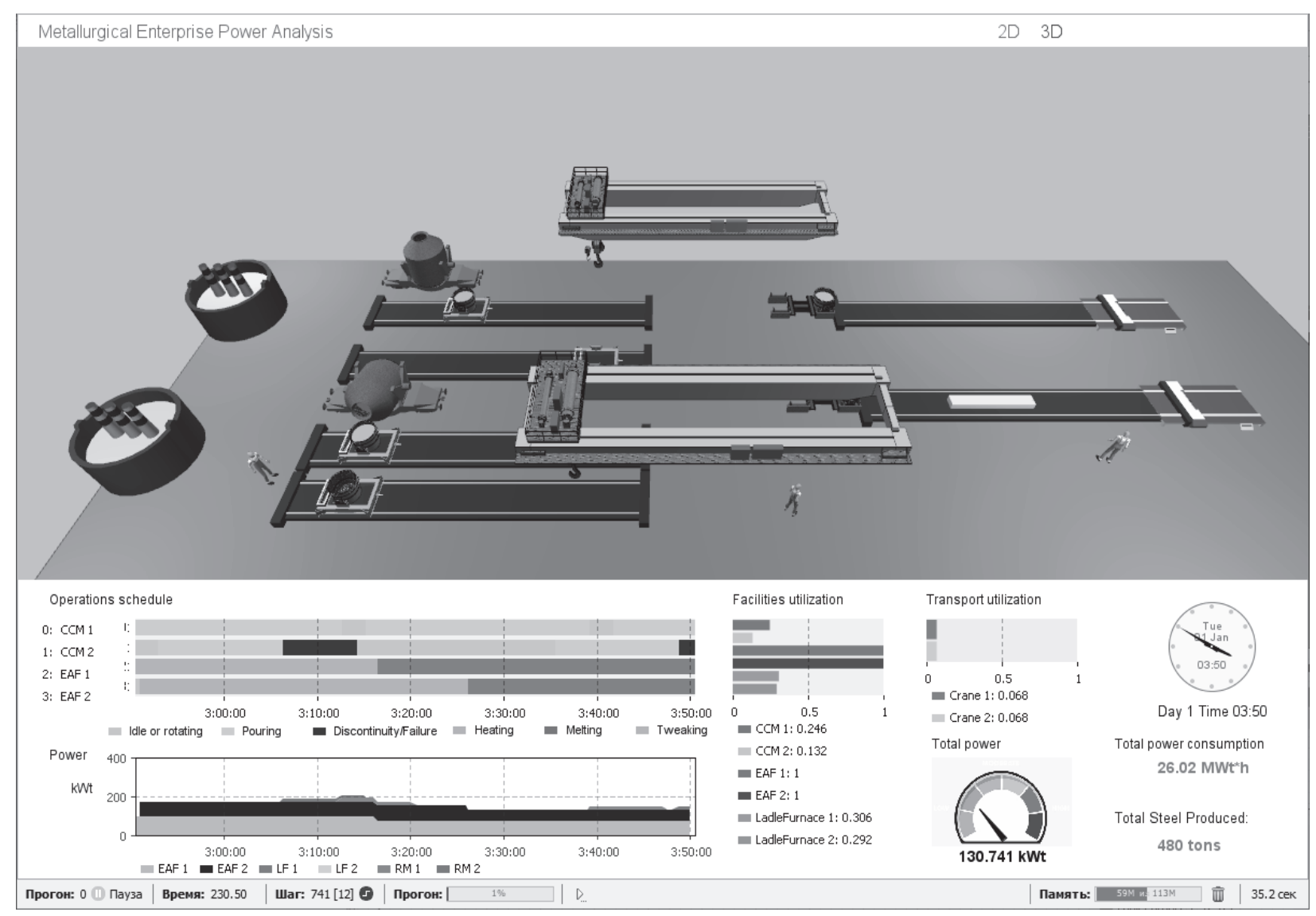

Рис. 2. Випробувальний стенд у процесі моделювання Джерело: розроблено автором.

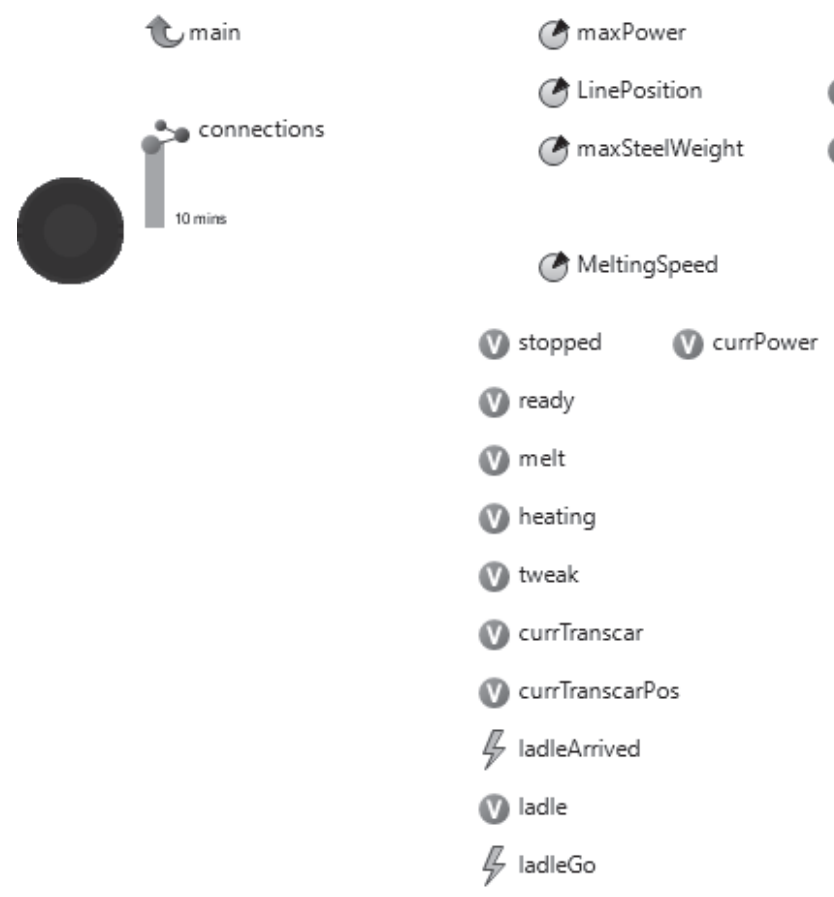

Рис. 3. Параметри, поведінка та візуалізація імітаційної моделі дугової сталеплавильної печі Джерело: розроблено автором. 


\section{Результати експериментів}

Було проведено експериментальні дослідження методів планування енергоспоживання на основі реальних даних з вироблення металопродукції і електроспоживання виробничими підрозділами ПрАТ “Дніпроспецсталь”.

В результаті моделювання вдалося підвищити продуктивність групи ДСП і АПК, знизити максимальне споживання активної потужності металургійним підприємством за фіксований час доби. Експериментальні дослідження методу планування показали, що використання розроблених алгоритмів призводить до зниження загальної помилки прогнозування електроспоживання (рис. 4). Результати проведення експериментальних досліджень методики планування електроспоживання показали, що підвищення точності прогнозу при погодинному плануванні на рівні окремих підрозділів за 2019 рік склало приблизно $8 \%$.

Апробація розроблених моделей і комп'ютерних засобів в ПрАТ “Дніпроспецсталь” показала, що можливе ефективне управління енергоефективністю на основі управління програмами і портфелями проектів. Так в період з 2017 по 2019 рік на підприємстві було реалізовано проектів з енергозбереження на загальну суму 2135 тис. грн. За допомогою даних проектів і заходів було заплановано і фактично досягнуто скорочення споживання природного газу на 1,5\% (0.61 тис. т. ум. палива), теплоенергії на 2\%. Вартість зекономлених енергоресурсів склала 5897,5 тис. грн. У порівнянні з 2011 роком споживання електроенергії на сталеплавильному виробництві знизилося на 30\%. Зменшилася також частка витрат на електроенергію для сталеплавильного виробництва з 71\% в 2011 до $67,8 \%$ в 2019 році.

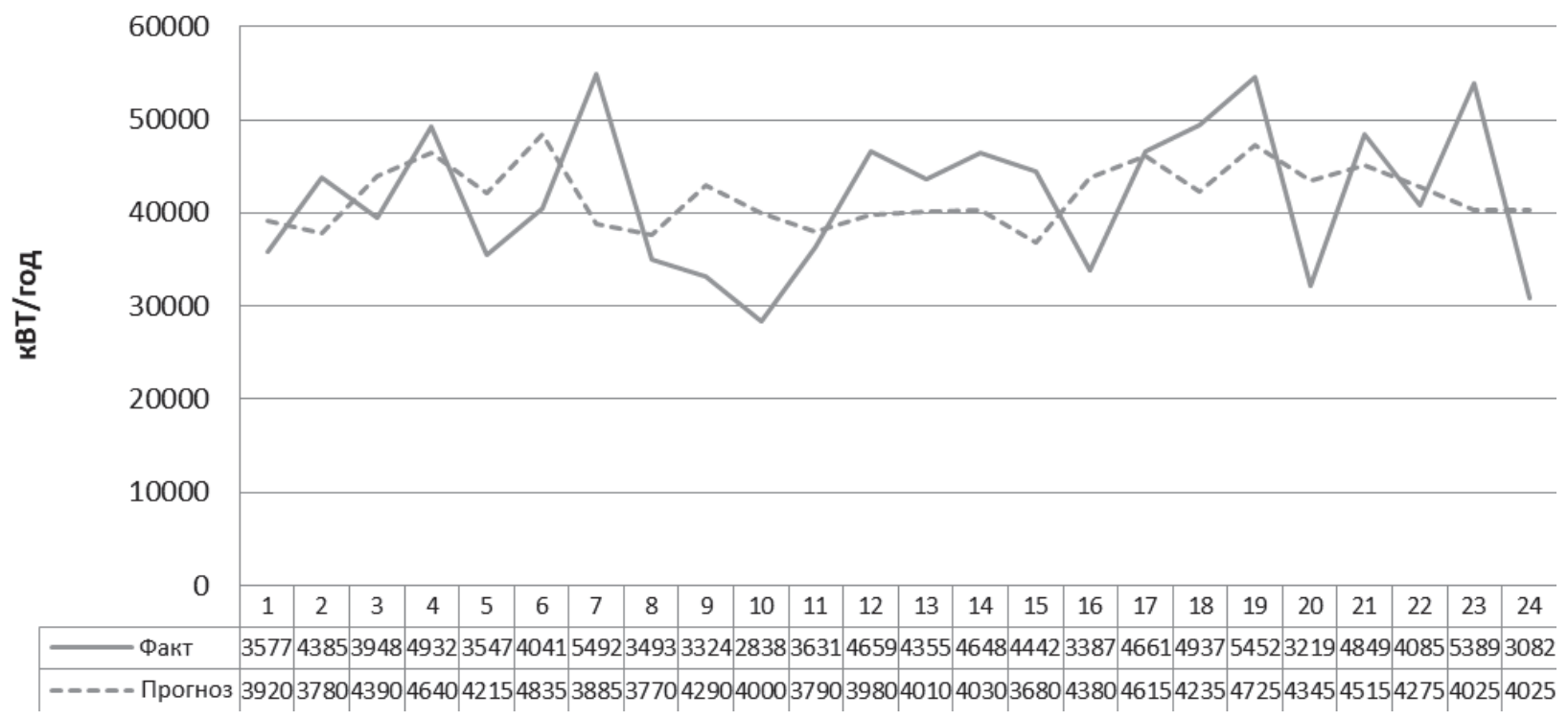

Рис. 4. Добовий прогноз і споживання електроенергії на ПрАТ “Дніпроспецсталь” Джерело: розроблено автором.

\section{Висновки}

Запропоновано методологію управління портфелями проектів енергозбереження на металургійних підприємствах, яка відрізняється формуванням парадигми предиктивної адаптації, що базується на взаємопов'язаних адаптивних системах планування, моніторингу і управління змінами та дозволяє на основі прогнозування енергоспоживання для складних технологічних процесів і виробництв, а також моделювання і оцінки якості паливно-енергетичного балансу, в умовах обмеженості ресурсів і ризиків здійснювати формування і відбір для реалізації проектів енергозбереження при узгодженні пріоритетів бізнес-стратегії і стратегії енергоефективності металургійного підприємства.
Розроблено імітаційну модель аналізу енергоспоживання металургійного підприємства та оцінювання якості паливно-енергетичного балансу. За допомогою моделі можливе вирішення цілого ряду завдань, серед яких оцінка раціональності та ефективності існуючої на підприємстві структури енергоспоживання, прогнозування очікуваних рівнів енерговитрат при зміні технології, сортаменту і якості продукції та порівняння різних технологій і обладнання $з$ точки зору енергоефективності, оптимальне управління потоками енергоносіїв з урахуванням зміни умов виробництва тощо.

Моделювання та оцінка якості паливноенергетичного балансу підприємства дозволяє за допомогою вихідних динамічних нормативів отримати певну систему похідних динамічних нормати- 
вів для адаптивного регулювання енергетичних активів металургійного підприємства, що забезпечує реалізацію ефективної стратегії енергоменеджменту металургійного підприємства при відборі проектів для стратегічного планування підвищення енергоефективності та енергозбереження виробництва.

\section{Список літератури}

1. Никифоров Г.В. Энергосбережение и управление энергопотреблением в металлургическом производстве / Г.В. Никифоров, В.К. Олейников, Б.И. Заславец. - М.: Энергоатомиздат, 2003. -480 с.

2. Белан А.В. Прогнозирование электропотребления на основе многофакторного регрессионного и корреляционного анализов / А.В. Белан, В.И. Гордеев // Проблемы энергосбережения. - 1991. - № 7. - С. 54-59.

3. Bianco V. Electricity consumption forecasting in Italy using linear regression models / V. Bianco, O. Manca, S. Nardini // Energy. - 2009. - № 34. - P. 1413-1421. https://doi.org/10.1016/j.energy.2009.06.034.

4. Dordonnat V. Dynamic factors in periodic time-varying regressions with an application to hourly electricity load modeling / V. Dordonnat, S.J. Koopman, M. Ooms // Computational Statistics and Data Analysis. - 2012. - № 56. - P. $3134-3152$. htpps://doi.org/10.1016/j.csda.2011.04.002.

5. Манусов В.З. Оценка и прогнозирование электропотребления в энергосистемах на основе нечеткого регрессионного анализа / В.З. Манусов, А.В. Могиленко, В.П. Костромин // Электрика. - 2003. - № 7. - С. 41-43.

6. Yujuan R. Modeling and Simulation of Metallurgical Process Based on Hybrid Petri Net / R. Yujuan, H. Bao // International Conference on Mechanical Engineering and Automation. - Singapore, 13-15 October 2016. - P. 157. htpps://doi.org/10.1088/1757-899X/157/1/012018.

7. An Energy Consumption Prediction LSTM Model of Metallurgy Enterprises / W. Xueying, Y. Zhuchao, X. Pengfei, C. Gaixia, L. Shiyang, L. Jing, Z. Yuanzheng // 4th International Conference on Environmental and Energy Engineering. Sanya, China. - 12-15 March 2020. - Vol. 495. - P. 012014. htpps://doi.org/10.1088/1755-1315/495/1/012014.

8. Development of a scheme for generating the predicted value of specific electricity consumption / I. Rakhmonov, A. Berdishev, N. Niyozov, A. Muratov, U. Khaliknazarov // International Scientific Conference Construction Mechanics, Hydraulics and Water Resources Engineering, Tashkent, Uzbekistan. - 23-25 April 2020. - Vol. 883. - P. 012103. htpps://doi.org/10.1088/1757-899X/883/1/012103.

9. Шеметов А.Н. Адаптивное управление режимами электропотребления промышленного объекта по комплексному критерию / А.Н. Шеметов, В.К. Олейников // Главный энергетик. - 2014. - № 4. - С. 30-37.

10. Цюцюра С.В. Управління інноваційними проектами модернізації підприємств енергоємних галузей: дис. ... д-ра техн. наук: 05.13.22 / С.В. Цюцюра. - К., 2007. - 342 с.

11. Новиков С.С. Оперативное прогнозирование электропотребления металлургического предприятия как средство снижения рыночных рисков / С.С. Новиков // Вестник Московского энергетического института. - 2008. - № 1. - С. 91-97.

12. Molokanova V. Project-oriented approach to metallurgical enterprises sustainable development management / V. Molokanova, V. Petrenko // Metallurgical and mining industry. - 2016. - № 8. - P. 28-35.

13. Management of energy saving project and programs at metallurgical enterprises / S.G. Kivko, E.A. Druzhinin, O.V. Prokhorov, D.N. Kritsky // 2019 IEEE 14th International Conference on Computer Sciences and Information Technologies, Lviv, Ukraine. - 17-20 September 2019. - pp. 158-161. https://doi.org/10.1109/STC-CSIT.2019.8929807.

14. Formation of metallurgical enterprise sustainable development portfolio using the method of analyzing hierarchies / V.M. Molokanova, O.P. Orliuk, V.O. Petrenko, O.B. Butnik-Syverskyi, V.L. Khomenko // Scientific Bulletin of the National Mining University. - 2020. - No. 2. - pp. 131-136. https://doi.org/10.33271/nvngu/2020-2/131.

15. Концептуальна модель управління проектами / К.В. Колеснікова, В.Д. Гогунський, А.О. Негрі, Г.С. Олех // Электротехнические и компьютерные системы. $\quad$ - 2016. $\quad$ - № 23(99). $\quad$ - $\quad$ С. $175-179$. http://dx.doi.org/10.15276/eltecs.23.99.2016.27.

16. Kolesnikova K. Modeling of Decision Making Strategies In Management of Steelmaking Processes / K. Kolesnikova, O. Mezentseva, O. Savielieva // 2019 IEEE International Conference on Advanced Trends in Information Theory. - Kyiv, Ukraine. - 18-20 December 2019. - pp. 455-460. htpps://doi.org/10.1109/ATIT49449.2019.9030524.

\section{Відомості про автора:}

\section{Кійко Сергій Геннадійович}

кандидат технічних наук

голова правління Електрометалургійного заводу

“Дніпроспецсталь” ім. А.М. Кузьміна,

Запоріжжя, Україна,

https://orcid.org/0000-0003-4676-5722

\section{Information about the author:}

\section{Sergey Kyiko}

Candidate of Technical Sciences

Chairman of the Board Electrometallurgical plant

"Dniprospetsstal" named after A.M. Kuzmin,

Zaporozhye, Ukraine

https://orcid.org/0000-0003-4676-5722 

НА МЕТАЛЛУРГИЧЕСКИХ ПРЕДПРИЯТИЯХ НА БАЗЕ ПРЕДИКТИВНОЙ АДАПТАЦИИ

\author{
С.Г. Кийко
}

Предложена методология управления портфелями проектов энергосбережения на металлургических предприятиях, которая формирует парадигму предиктивной адаптации, основанной на взаимосвязанных адаптивных системах планирования, мониторинга и управления изменениями и позволяет на основе прогнозирования энергопотребления для сложных технологических прочессов и производств, а также моделирования и оценки качества топливноэнергетического баланса, в условиях ограниченности ресурсов и рисков осуществлять формирование и отбор для реализации проектов энергосбережения при согласовании приоритетов бизнес-стратегии и стратегии энергоэффективности металлургического предприятия. Построена агентная имитационная модель для решения задач по управлению распределением энергоресурсов, которая основана на взаимодействии агентов поставщиков, потребления, производства и преобразования энергоресурсов, выполняющих поиск соответствия на внутризаводском рынке наличных энергоресурсов или внешнем энергорынке, что позволяет комплексно с учетом динамики производственных проиессов проводить анализ и выбор вариантов реализации проектов портфеля энергосбережения. С помощью этого программного комплекса проводится сравнение допустимых значений и корректировка величины прогнозируемого потребления активной мощности металлургического предприятия за каждый фиксированный момент времени. Система вычисляет диапазоны регулирования режимов дуговых электропечей, допустимые для обеспечения непрерывности разливки стали при плавке определенного сортамента стали по соответствующим технологическим маршрутам. Также в модель заложены алгоритмы управления транспортным оборудованием, которые минимизируют разрывы в работе машин непрерывного литья. Проведен анализ результатов имитационного моделирования проиессов энергопотребления на металлургическом предприятии. В результате моделирования удалось повысить производительность группы дуговых сталеплавильных печей и агрегатов печь-ковщ, снизить максимальное потребление активной мощности металлургическим предприятием за фиксированное время суток. Проведены экспериментальные исследования методов планирования энергопотребления на основе реальных данных по производству металлопродукиии и электропотребления производственными подразделениями ЧАО “Днепроспеисталь”.

Ключевые слова: портфель проектов, управление энергосбережением, металлургическое предприятие, планирование энергопотребления, агентная модель.

\title{
ENERGY CONSUMPTION PLANNING IN THE IMPLEMENTATION OF THE PORTFOLIO OF ENERGY SAVING PROJECTS AT THE METALLURGICAL ENTERPRISE ON THE BASIS OF PREDICTIVE ADAPTATION
}

\section{S. Kiyko}

A methodology for managing portfolios of energy saving projects in metallurgical enterprises is proposed, which forms a paradigm of predictive adaptation based on interconnected adaptive systems of planning, monitoring and change management and allows based on energy consumption forecasting for complex technological processes and productions, as well as modeling and evaluation energy balance, in the conditions of limited resources and risks to carry out formation and selection for realization of projects of energy saving at coordination of priorities of business strategy and strategy of energy efficiency of the metallurgical enterprise. An agent simulation model for solving energy distribution management tasks has been built, which is based on the interaction of suppliers, consumption, production and conversion agents performing compliance in the in-plant market of available energy resources or external energy market, which allows comprehensive analysis of production processes implementation of energy saving portfolio projects. With the help of this software package the comparison of admissible values and adjustment of the value of the forecasted consumption of active power by the metallurgical enterprise for each fixed moment of time is carried out. The system calculates the control ranges of electric arc furnaces, which are permissible to ensure the continuity of steel casting during the melting of a certain range of steel along the appropriate technological route. The mod-el also includes algorithms for controlling transport equipment that minimize interruptions in the operation of continuous casting machines. The analysis of the results of simulation modeling of energy consumption processes at the metallurgical enterprise is carried out. As a result of modeling it was possible to increase the productivity of a group of arc steelmaking furnaces and ladle furnace units, to reduce the maximum consumption of active power by a metallurgical enterprise for a fixed time of day. Experimental studies of energy consumption planning methods based on real data on the production of metal products and electricity consumption by production departments of PJSC "Dniprospetsstal" were conducted.

Keywords: project portfolio; energy saving management; metallurgical enterprise, energy consumption planning, agent model. 